\title{
Combination of SAR remote sensing and GIS for monitoring subglacial volcanic activity - recent results from Vatnajökull ice cap (Iceland)
}

\author{
K. Scharrer ${ }^{1}$, R. Malservisi ${ }^{2}$, Ch. Mayer ${ }^{3}$, O. Spieler ${ }^{4}$, and U. Münzer ${ }^{1}$ \\ ${ }^{1}$ Ludwig-Maximilians-University, Department of Earth and Environmental Sciences, Section Geology, Luisenstr. 37, 80333 \\ Munich, Germany \\ ${ }^{2}$ Ludwig-Maximilians-University, Department of Earth and Environmental Sciences, Section Geophysics, Theresienstrasse \\ 41, 80333 Munich, Germany \\ ${ }^{3}$ Bavarian Academy of Sciences and Humanities, Commission for Glaciology, Alfons-Goppel Str. 11, 80539 Munich, \\ Germany \\ ${ }^{4}$ Ludwig-Maximilians-University, Department of Earth and Environmental Sciences, Section Mineralogy, Petrology and \\ Geochemistry, Theresienstrasse 41, 80333 Munich, Germany
}

Received: 1 June 2007 - Revised: 25 October 2007 - Accepted: 9 November 2007 - Published: 27 November 2007

\begin{abstract}
This paper presents latest results from the combined use of SAR (Synthetic Aperture Radar) remote sensing and GIS providing detailed insights into recent volcanic activity under Vatnajökull ice cap (Iceland). Glaciers atop active volcanoes pose a constant potential danger to adjacent inhabited regions and infrastructure. Besides the usual volcanic hazards (lava flows, pyroclastic clouds, tephra falls, etc.), the volcano-ice interaction leads to enormous meltwater torrents (icelandic: jökulhlaup), devastating large areas in the surroundings of the affected glacier. The presented monitoring strategy addresses the three crucial questions: When will an eruption occur, where is the eruption site and which area is endangered by the accompanying jökulhlaup. Therefore, sufficient early-warning and hazard zonation for future subglacial volcanic eruptions becomes possible, as demonstrated for the Bardárbunga volcano under the northern parts of Vatnajökull. Seismic activity revealed unrest at the northern flanks of Bardárbunga caldera at the end of September 2006. The exact location of the corresponding active vent and therefore a potentially eruptive area could be detected by continuous ENVISAT-ASAR monitoring. With this knowledge a precise prediction of peri-glacial regions prone to a devastating outburst flood accompanying a possible future eruption is possible.
\end{abstract}

\section{Ice-Volcano interactions in Iceland}

As the recent formation of the IAVCEI (International Association of Volcanology and Chemistry of the Earth's Interior) working group of Volcano-Ice interactions demonstrates, the interactions and hazardous effects of subglacial volcanic eruptions are a growing and highly up to date study field. Glaciers atop active volcanoes pose a constant potential danger to adjacent inhabited regions and infrastructure. Besides the usual volcanic hazards (lava flows, pyroclastic clouds, tephra falls, etc.), the volcano-ice interaction leads to enormous meltwater torrents (icelandic: jökulhlaup), devastating large areas in the surroundings of the affected glacier. The subglacial eruption of Gjálp (30 September-13 October 1996) beneath Vatnajökull and the subsequent jökulhlaup (5-7 November 1996) are a good example of the hazardous nature of such an event. During this $48 \mathrm{~h}$ cataclysm, a volume of $3.2 \mathrm{~km}^{3}$ of meltwater was discharged at peak rates of about $4 \times 10^{4} \mathrm{~m}^{3} \mathrm{~s}^{-1}$, destroying the local infrastructure (roads, bridges, dams, power and telephone lines, etc.) in the adjacent Skeidarársandur (Björnsson, 2002).

Only a multidisciplinary approach seems capable of addressing the manifold questions arising with this phenomenon, where we present latest results from the combined utilisation of SAR (Synthetic Aperture Radar) remote sensing and GIS providing detailed insights into recent volcanic activity under Vatnajökull ice cap.

Correspondence to: $\mathrm{K}$. Scharrer

(k.scharrer@iaag.geo.uni-muenchen.de)

Published by Copernicus Publications on behalf of the European Geosciences Union. 


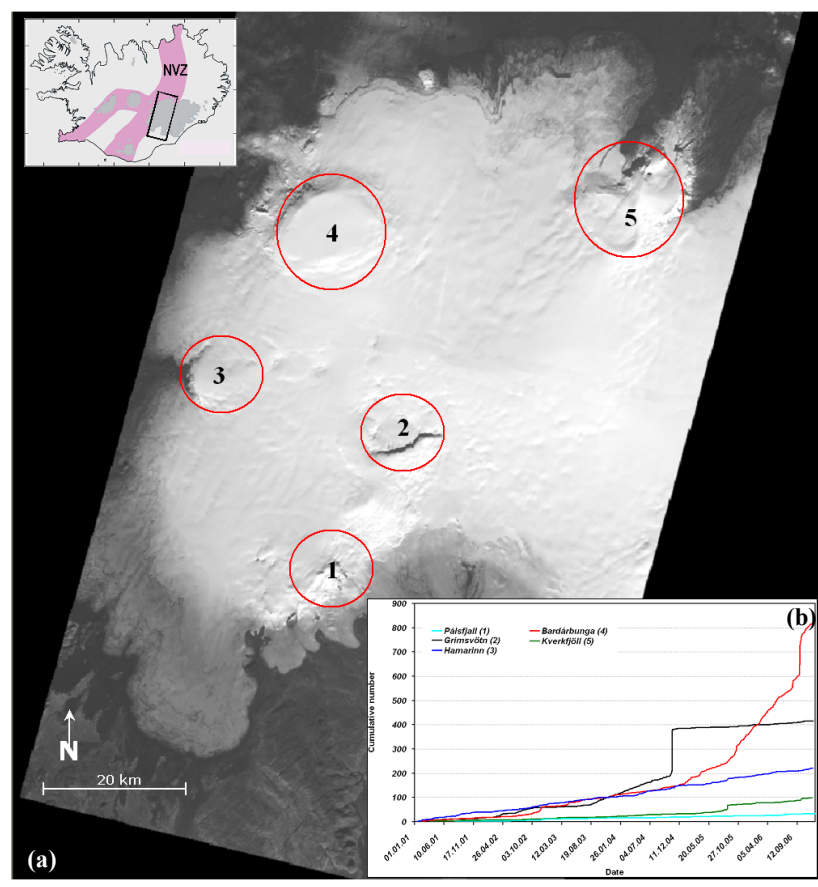

Fig. 1. (a) ASTER-Mosaic (C) NASA 2004) of the western part of Vatnajökull ice cap. Numbered red circles indicate the locations of subglacial volcanic systems. The most active volcanoes are the Grímsvötn (2) and the Bardárbunga-Veidivötn (4) systems. The insert map illustrates the geographic extent of Figure 1a and the Neovolcanic Zone (NVZ) crossing Iceland. (b) shows the cumulative number of earthquakes observed at the different volcanic centres (1-5) beneath western Vatnajökull from 01/01/2001 until 31/12/2006. At Pálsfjall (1), Hamarinn (3) and Kverkfjöll (5) no significant changes in activity are developed since 2001, whereas the 2004 eruption at Grímsvötn (2) is clearly reflected in the data. A prominent increase in seismic activity is pronounced at Bárdarbunga (4) since December 2004.

\section{Subglacial volcanoes Grímsvötn and Bardárbunga}

In Iceland, several active central volcanoes, crater chains and fissures are covered by glacier ice. Several of Iceland's most active and dangerous volcanic centres (Fig. 1) are covered by the largest European glacier, Vatnajökull (approximately $8100 \mathrm{~km}^{2}$ ) (Björnsson and Einarsson, 1990; Adalgeirsdóttir, 2003). The Neovolcanic zone, an active section of the MidAtlantic ridge responsible for the high seismic and volcanic activity, propagates under the western parts of Vatnajökull ice cap. Furthermore, this area is the centre of the Iceland mantle plume (Wolfe et al., 1997; Shen et al., 2002).

The Grímsvötn volcanic system shows the highest eruption frequency of all subglacial volcanoes beneath Vatnajökull with about 70 eruptions in historical time (Thordarson and Larsen, 2007). The about $62 \mathrm{~km}^{2}$ large caldera of the central volcano is situated in the central part of western Vatnajökull (Fig. 1). The adjacent fissure swarm extends about
$90 \mathrm{~km}$ in south-westerly direction. The southern rim of the caldera protrudes through the ice cover at an elevation of $1722 \mathrm{~m}$ a.s.l., whereas the rest of the crater rim is covered by the ice cap. The caldera (approx. $1450 \mathrm{~m}$ a.s.l.) is filled by the geothermally heated subglacial lake Grímsvötn, which is overlain by glacier ice up to $250 \mathrm{~m}$ thick (Björnsson and Einarsson, 1990). Due to the constant heat flux in the caldera, jökulhlaups occur even without an eruption. Meltwater accumulates in the caldera, until the subglacial lake reaches a critical level. Then, water pressure breaks the glacial seal and a floodwave travels over a distance of $50 \mathrm{~km}$ subglacially under the Skeidarárjökull outlet and finally reaches the huge plain Skeidarársandur in the South (Björnsson, 1992). Meltwater production rates during eruptions at Grímsvötn can increase by several orders of magnitude, leading to devastating outburst floods as the previously mentioned 1996 jökulhlaup.

The second most active volcano beneath Vatnajökull is the Bárdarbunga-Veidivötn volcanic system (Thordarson and Larsen, 2007). At least 23 eruptions are attributed to this system in historical time. The volcanic system consists of the Bárdarbunga central volcano, where eruptive activity is highest, and an associated $190 \mathrm{~km}$ long south-westward trending fissure swarm. Bárdarbunga is a large volcanic edifice girding an about $80 \mathrm{~km}^{2}$ large caldera. The topographic caldera rim reaches an elevation of $1500-1850 \mathrm{~m}$, whereas its bottom is at $1100 \mathrm{~m}$ a.s.l. The central volcano and about $60 \mathrm{~km}$ of the fissure swarm are covered by up to $850 \mathrm{~m}$ thick glacier ice (Björnsson and Einarsson, 1990). Several eruptions from the ice covered central volcano were accompanied by jökulhlaups, draining via the river Jökulsá á Fjöllum to the North.

Both, eruptions of Bárdarbunga and Grímsvötn show the same character. A single vent or part of a fissure erupts highly fragmented basaltic tephra in hydromagmatic eruptions, producing extensive tephra layers (Thordarson and Larsen, 2007). Larsen et al. (1998) used such tephra layers, preserved in ice cores and soil records, to reconstruct the eruption frequency of the volcanic systems under Vatnajökull. They found, that the volcanic activity has a 130 140 year periodicity, where $40-80$ year long intervals of high eruption frequency alternate with low frequency intervals of about equal length. The mainspring of the cycle seems to be the Grímsvötn volcanic system. Other systems join in when activity is high at Grímsvötn, especially the BárdarbungaVeidivötn system. Considering the recent eruptive activity at Grímsvötn with three eruptions in the past decade (1996, 1998 and 2004) and the predictions of the tephrochronological record it seems likely, that the next 60-80 years are characterised by an interval of high activity (Larsen et al., 1998; Larsen et al., 2005).

\section{Monitoring strategy}

Considering the impacts of subglacial volcanic eruptions three major questions have to be addressed for sufficient 
early-warning and hazard zonation: When will an eruption occur, where is the eruption site and which area is endangered by the accompanying jökulhlaup.

As earthquake activity beneath a volcano almost always increases before an eruption, the "when" question can be addressed by seismic monitoring. In Iceland a nationwide digital network of 44 seismic stations is operated, to monitor seismic and volcanic activity (Bödvarsson et al., 1999). The importance of seismicity as tool to indicate an imminent eruption in Iceland, was clearly shown during the 2004 Grímsvötn eruption under the Vatnajökull ice cap. The considerable increase of earthquake activity beneath Grímsvötn lead to a detailed warning about $24 \mathrm{~h}$ prior to the beginning of the eruption and the network proved its applicability for eruption forecasting (Vogfjörd et al., 2005).

Potential subglacial eruption sites can only be identified indirectly due to the ice cover. Ascent of magma in a volcanic edifice leads to an increased heat flux at the active vent or fissure well before its arrival to the surface. Due to the plasticity of ice, a volume loss at the glacier bottom, triggered by ice melting from geothermal activity, leads to a depression in the glacier surface. A circular depression develops over a more or less punctiform geothermal active spot and can therefore be detected with remote sensing techniques. Due to its special characteristics, SAR (Synthetic Aperture Radar) remote sensing is an appropriate method for monitoring glacier deformation and thus potentially eruptive vents. One of the main advantages of SAR monitoring, especially in the light of the Icelandic weather conditions, is its independence from cloud cover and day light allowing a continuous monitoring. Further, the ability to penetrate the upper layers of snow and firn enables the detection of buried topographic features on the glacier surface which are related to subglacial volcanic activity.

A first attempt to utilise satellite SAR data for monitoring a subglacial volcanic eruption in Iceland was carried out by Müschen et al. (1997). They used data of the satellites ERS-1 and ERS-2 to monitor the impacts of the Gjálp eruption under Vatnajökull in October 1996. Both amplitude and phase information were analysed to estimate the dimensions of the active fissure, the disturbed area of the glacier and therefore the amount of meltwater produced during this event. Further they mapped the areas affected by the accompanying jökulhlaup in the adjacent sandur plain. Nevertheless, it was only a temporary study watching the course of this subglacial eruption, but the early-warning potential of a continuous SAR monitoring was not exploited.

Since November 2002 the ASAR (Advanced Synthetic Aperture Radar) sensor carried by the ENVISAT satellite collects data over Vatnajökull within the ESA project "Hazard Assessment and Prediction - Long-term Observation of Icelandic Volcanoes and Glaciers Using ENVISAT-ASAR and Other Radar Data (ID 142)“. The ASAR instrument is a side looking C-band SAR antenna operating at a wavelength of $5.6 \mathrm{~cm}$. Due to its beam steering capability the ASAR instrument can acquire images in seven different swathes (IS1 - IS7), covering an incidence angle range from 15 to 45 degrees. Images of the swathes IS 2 (incidence angle 21.5 and IS 5 (incidence angle $37.5^{\circ}$ ) are continuously acquired over the ice cap for monitoring the subglacial volcanic activities with a temporal repetition of up to nine days including ascending (asc) and descending (desc) orbits.

As aforementioned, an increased heat flux at an active vent or fissure causes a depression in the glacier surface. If deformation at such a depression is high enough to cause fracture, then the sink is surrounded by crevasses. Due to surface roughness the crevasses result in high backscatter values in SAR images that can easily be used to outline the ice cauldron and therefore indicate the area of increased geothermal activity at the glacier bed. Further, the slopes and floor of a depression often appear darker in SAR images (lower backscatter) than the undisturbed surrounding area. This is caused by accumulation of fine grained snow due to wind drift or a higher moisture content at the slopes receiving a higher amount of solar radiation (Henderson and Lewis 1998). However, backscatter intensity in particular varies strongly with the annual and short-term weather conditions on a glacier. This sensitivity of the SAR signal to variations in environmental conditions hinders a standard protocol for analysing the SAR data. Thus, continuous SAR monitoring enables the identification of active vents or fissures under an ice cap, by mapping the related circular depressions in the glacier surface, but the interpretation is still empiric and dependent on the user experience.

The potential of continuous SAR monitoring for early detection of active vents or fissures could be tested and demonstrated during a subglacial volcanic eruption under Vatnajökull in autumn 2004. ASAR image analysis during the last Grímsvötn eruption (1 November until 7 November 2007) showed that 8 days ahead of the eruptive phase on 24 October 2004 the exact position of the eruption site inside the caldera could be located through the glacial ice cover due to the increased geothermal activity preceding the eruption. $35 \mathrm{~h}$ prior to the outbreak, on 31 October 2004, the extent could be detected in detail (Fig. 2a-c). In case of the thick Icelandic glaciers, meltwater produced by a subglacial eruption propagates subglacially from the eruption site to the glacier terminus (Björnsson, 1988). The prediction of jökulhlaup paths is based on drainage basins of the glaciated areas derived from a potential map describing the sum of the gravitational and the pressure potential at the glacier bed (Björnsson, 2002). By comparison of the location of a potential eruption site with the drainage basins, the areas in the surroundings of the glacier endangered by a jökulhaup can be identified. Therefore exact knowledge about the location of a subglacial eruption site is again crucial for the prediction of the potentially affected river catchment.

Both, the ground data (epicentres and glacial drainage basins) and the remotely sensed ENVISAT-ASAR images have a spatial component and can therefore be organized 


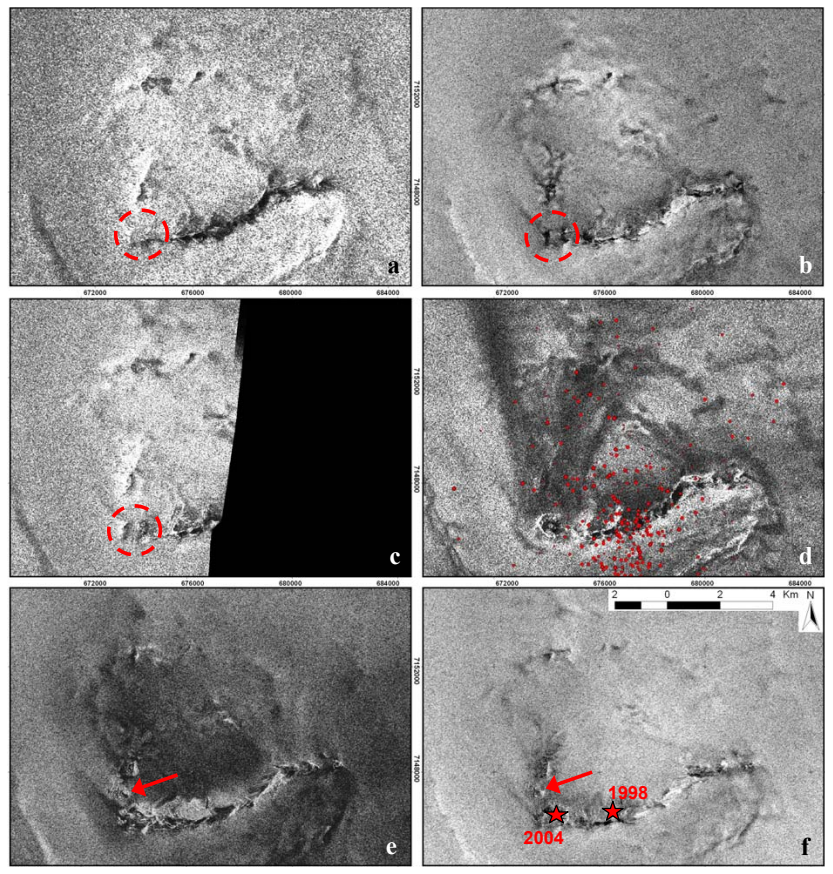

Fig. 2. Important acquisitions of the ENVISAT-ASAR time series showing the Grímsvötn caldera. On 31 August 2004 the southwestern part of the caldera shows no distinctive feature (a). Eight days prior to the eruption (24/10/2004) the active area can already be detected (b). On 31 October 2004 (c) the eruption site inside the caldera (red circle) could be located in detail through the glacial ice cover about $35 \mathrm{~h}$ prior to the eruptive phase due to the increased geothermal activity. The scene acquired on 13 November 2004 (d) seven days after the eruption shows the eruption site with the northerly deposited tephra fans. Locations of epicentres detected in 2004 (red dots, (C) Icelandic Meteorological Office) indicate the difficulty of an exact location of a potential eruption site under a glacier by the analysis of seismic data only. In the ASAR image acquired on 18 August 2005 (e) the new depression (red arrow) appears for the first time. It is although detectable on 02 December 2006 (f). Considering the locations of the eruption sites in 1998 and 2004 a westward migration of the activity along the ring fault of the caldera is evident. (C) ESA 2004-2006

in a GIS database. It was already found by Müschen et al. (1997) that the time span between acquisition of a SAR image, data processing and analysis, and briefing of local authorities about new results is a crucial component for early warning. Hence, an automated processing chain has been developed for continuous and fast integration of newly acquired ENVISAT-ASAR scenes into the GIS environment (Gutjahr et al., 2006; Gutjahr and Scharrer, 2007). This processing chain utilises a network of artificial corner reflectors installed around Icelandic glaciers. The high backscatter values of these reflectors are detected automatically, leading to a fully automated ortho-rectification of the SAR images reducing the processing time significantly. Finally, the unified reference system (UTM, WGS 84, Zone 27) within the GIS database allows a combination and correlation of the layers (epicentres, glacial drainage basins, and SAR images) to enable near real time hazard monitoring and risk prediction at Vatnajökull ice cap. Risk assessment and prediction models can be made available whenever needed (Münzer et al., 2005).

\section{Recent activities at Bárdabunga and Grímsvötn}

Recent earthquake data of the central volcanoes under the western part of Vatnajökull gives a good indication of the activity level of the various volcanic systems (Fig. 1b). At Pálsfjall (1), Hamarinn (3) and Kverkfjöll (5) no significant changes in activity are developed since 2001 , whereas the 2004 eruption at Grímsvötn (2) is clearly reflected in the data. Looking at the seismic activity at Bárdarbunga (4) central volcano, with its prominent increase since December 2004, it seems likely that the last Grímsvötn eruption triggered the re-awakening of Bárdarbunga. So far the increase culminated in an extensive earthquake swarm in September 2006. It started on 23 September 2006 and lasted until 30 September 2006, with the highest activity on 26 September 2006. The strongest event reached a local magnitude of 3.8 on 24 September 2006, whereas the vast majority of events had local magnitudes between 1 and 2.5. The epicentres scattered around two focal areas, one directly at the northern slopes of Bárdarbunga caldera, a second one about $10 \mathrm{~km}$ to the North close to the glacier margin (Fig. 3a). The uncertainty if the scattering is related to 2 spatially different areas of activity, highlights the difficulty of an exact location of a potential eruption site under a glacier by the analysis of seismic data alone. Looking at the distribution of earthquake epicentres preceding the 2004 Grímsvötn eruption, the same problem appears (Fig. 2d). In the eruption warnings released by the Icelandic Meteorological Office only statements like "an eruption site at or near Grímsvötn" were possible (Vogfjörd et al., 2005).

Recent ASAR monitoring showed, that a new surface depression formed after the 2004 eruption in their northwestern vicinity (X: 673670.425 / Y: 7147193.930; UTM, WGS 84, Zone 27N), first detectable in ENVISAT-ASAR scenes acquired in August 2005 (Fig. 2e,f). Considering the locations of the eruption sites in 1998 and 2004 a westward migration of the activity along the ring fault of the caldera is evident (Fig. 2f). When seismic activity at Grimsvötn increases again, this location should be in the focus because from our investigations the eruption site can be expected there. A future eruption at this location would cause a jökulhlaup via the Skeidarárjökull to the south.

Due to the abrupt increase of seismic activity at Bardárbunga end of September 2006, ENVISAT-ASAR's beam steering capability was fully utilised (antenna swathes IS1IS7) until December 2006, leading to a sequence with at least two ASAR scenes per week. Therefore activity at 
Bardárbunga could be monitored with very high temporal resolution. Simultaneous ASAR acquisition at the onset of the swarm activity on 23 September 2006 revealed the formation of two new ice depressions on the glacier surface (western depression X: 674496.845 / Y: 7178725.540 ; eastern depression X: 674862.662 / Y: 7178499.952; UTM, WGS 84, Zone $27 \mathrm{~N}$ ) (Fig. 3b, c). Both sink holes have approximately the same diameter of about $200 \mathrm{~m}$. They are associated to the earthquake cluster at the northern slopes of the Bárdarbunga caldera, indicating the area of increased geothermal activity. Matching of their locations with drainage basins predicts a jökulhlaup path to the north via the river system Jökulsá á Fjöllum. Accompanied by the decreased seismic activity in November and December 2006 no further variation of these surface features could be detected. The two new surface depressions were probably refilled by accumulating snow and are not visible anymore in current ASAR images. Without a continuous ASAR monitoring, the two depressions would not have been recognized.

\section{Conclusions}

By applying a combined observation of seismicity and SAR monitoring sufficient early-warning of a subglacial volcanic eruption at Vatnajökull is possible. Continuous ASAR monitoring enables the identification of active vents or fissures under the ice cap and therefore an improved hazard zonation of areas endangered by a jökulhlaup accompanying a subglacial eruption. Seismic monitoring gives a good indication of the point in time an eruption is imminent. Considering the predicted period of high volcanic activity, the increased seismic activity since 2004 at Bardárbunga and the detected increased heat flux at the northern slopes of the caldera, it seems likely that the next subglacial volcanic eruption under Vatnajökull will occur at the northern flank of Bardárbunga at the location of the newly detected surface depressions. As glaciovolcanism is a worldwide phenomenon responsible for several disasters in the past, we suggest a widespread application of SAR monitoring for early detection of potentially eruptive areas improving existing early warning capabilities and hazard zonation. Knowing the potentially dangerous areas before an eruption starts is critical for planning emergency procedures that can help ensure public safety if the unrest leads to eruptive volcanic activity.

Acknowledgements. ENVISAT-ASAR data were kindly provided by the European Space Agency (ESA). Thanks to the Icelandic Meteorological Office (Vedurstofa), Reykjavík, for the earthquake data. The research was made possible by the Bavarian Research Foundation (DPA 37/04). Sincere thanks are given to this institution. This paper was improved substantially following comments of D. Remy, an anonymous reviewer, and of the scientific editor F. Guzzetti .

\section{Edited by: F. Guzzetti}

Reviewed by: D. Remy and another anonymous referee

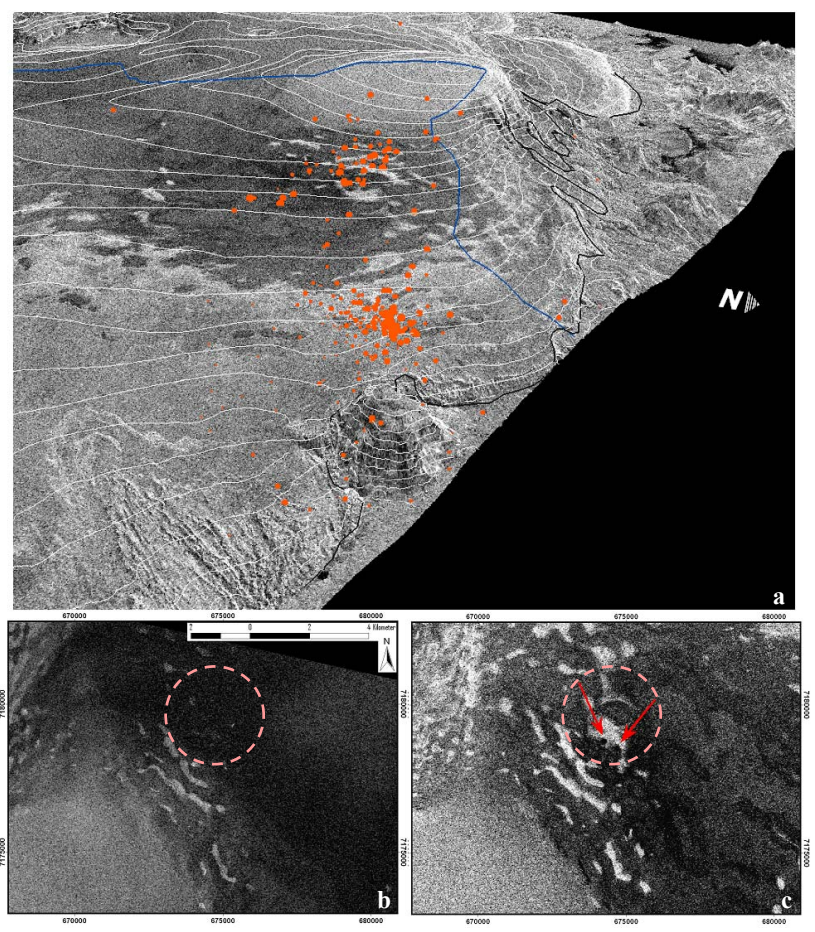

Fig. 3. Recent activity at the northern slopes of Bardárbunga caldera. 3-D-view (a) of the ASAR image 23 September 2006 including epicentres at Bardárbunga in 2006 (red dots, (C) Icelandic Meteorological Office) and the water divide girding the glaciated area (blue line) draining to the north via the river Jökulsá á Fjöllum. White lines indicate $50 \mathrm{~m}$ contour lines. Epicentres are distributed around to focal areas. Figure (b) (ENVISAT-ASAR 05/09/2006) shows the northern slopes of Bárdarbunga before the extensive earthquake swarm, starting on 23/09/2006 and lasting until 30 September 2006. The brighter features indicate crevassed areas. Simultaneous ASAR acquisition at the onset of the swarm activity on 23 September 06 (c) revealed the formation of two new ice depressions on the glacier surface. A future eruption at this location would trigger a jökulhlaup to the north via the river system Jökulsá á Fjöllum.@ ESA 2006

\section{References}

Adalgeirsdóttir, G.: Flow dynamics of Vatnajökull ice cap, Iceland, Ph. D. thesis, ETH Zürich, 2003.

Björnsson, H.: Hydrology of ice caps in volcanic regions, Reykjavík, Soc. Sci. Isl., 45, 139 pp., 1988.

Björnsson, H.: Subglacial lakes and jökulhlaups in Iceland, Global Planet. Change, 35, 255-271, 2002.

Björnsson, H. and Einarsson, P.: Volcanoes beneath Vatnajökull, Iceland: Evidence from radio echo-sounding, earthquakes and jökulhlaups, Jökull, 40, 147-169, 1990.

Björnsson, H.: Jökulhlaups in Iceland: prediction, characteristics and simulation, Ann. Glaciol., 16, 95-106, 1992.

Bödvarsson, R., Rögnvaldsson, S. T., Slunga, R., and Kjartansson, E.: The SIL data acquisition system at present and beyond year 2000, Phys. Earth Planet. Inter., 113, 89-101, 1999.

Gutjahr, K. H. and Scharrer, K.: Benefits of robust parame- 
ter estimation techniques in an automated geocoding processing chain, ISPRS Workshop 2007, 29 May-1 June 2007, Hannover, Germany, available online http://www.ipi.uni-hannover. de/fileadmin/institut/pdf/gutjahr_scharrer.pdf, 2007.

Gutjahr, K. H., Scharrer, K., and Münzer, U.: Utilizing the CRNetwork in Iceland for an automated interferometric processing chain - case study with ERS-Tandem data, ESA SP-610, 2006.

Henderson, F. M. and Lewis, A. J. (Eds.): Principles and Application of Imaging Radar, Manual of Remote Sensing, 3rd Edition, Vol. 2. John Wiley and Sons, New York, 1998

Larsen, G., Gudmundsson, M. T., and Björnsson, H.: Eight centuries of periodic volcanism at the center of the Icelandic hotspot revealed by glacier tephrostratigraphy, Geology, 26, 943-946, 1998.

Larsen, G., Gudmundsson, M. T., and Björnsson, H.: Increased Eruption Frequency in Volcanoes below the Vatnajökull Ice Cap, Iceland, predicted by Tephrachronology, Geophys. Res. Abstracts, 7, 10 066, Sref-ID: 1607-7962/gra/EGU05-A-10066, 2005.

Münzer, U., Scharrer, K., Weber-Diefenbach, and K., Gudmundsson, Á.: Integration of ENVISAT-ASAR Data in a HazardMonitoring-GIS, ENVISAT-Project [ID 142], ESA SP-572, 2005.
Müschen, B., Böhm, C., Roth, A., Schwäbish, M., and Holz, A.: Monitoring of subglacial volcanic eruption and glacial flood in southern Iceland using ERS-1/2 SAR data, ESA SP-405, 263271, 1997.

Shen, Y., Solomon, S. C., Bjarnason, I. TH., Nolet, G., Morgan, W. J., Allen, R. M., Vogfjörd, K., Jakobsdóttir, S., Stefánsson, R., Julian, B. R., and Foulger, G. R.: Seismic evidence for a tiled mantle plume and north-south mantle flow beneath Iceland, Earth Planet. Sc. Lett., 197, 261-272, 2002.

Thordarson, T. and Larsen, G.: Volcanism in Iceland in historical time: Volcano types, eruption styles and eruptive history, J. Geodyn., 43, 118-152, 2007.

Vogfjörd, K., Jakobsdóttir, S., Guðmundsson, G. B., Roberts, M. J., Ágústsson, K., Arason, T., Geirsson, H., Karlsdóttir, S., Hjaltadóttir, S., Ólafsdóttir, U., Thorbjarnardóttir, B., Skaftadóttir, T., Sturkell, E., Jónasdóttir, E. B., Hafsteinsson, G., Sveinbjörnsson, H., Stefánsson, R., and Jónsson, T. V.: Forecasting and Monitoring a Subglacial Eruption in Iceland, Eos Trans. AGU, 86, 245-252, 2005.

Wolfe, C. J., Bjarnason, I. Th., VanDecar, J. C., and Solomon, S. C.: Seismic structure of the Iceland mantle plume, Nature 385, 245-247, 1997. 